\title{
Effect of White Corn or Sweet Potato Flour on Quality Attributes of Gluten- Free Rice Cake
}

\author{
Eman Abd El-Hamid Ahmad Abd Rabou \\ Home Economics Dept., Fac. Specific Education, Aswan Univ., Egypt
}

Received: $8 / 1 / 2018$

\begin{abstract}
Gluten free rice cake samples were prepared by replacing white rice flour by white corn (Zea mays L) or sweet potato (Ipomoea batatas L.) flour at different levels. The chemical compositions, physical and sensory properties of cake samples were studied. The results showed that the moisture, protein, fat, ash and fiber contents were increased by increasing the substitution levels of white corn flour but the carbohydrate contents were decreased. Besides, the specific gravity values of cake batter and the baking loss values were decreased, but the specific volumes of the resultant cakes were increased. Furthermore, all sensory properties of cake samples were gradually increased but it was decreased in cake contained $67 \%$ and $83 \%$ white corn flour compared to other cake samples. Moreover, the results of the effect of increasing the levels of sweet potato flour on rice-sweet potato cake samples showed that the moisture, fat, ash and fiber contents were increased, but the protein and carbohydrate contents were decreased. The specific gravities of cake batter and the baking loss and specific volume values of the resultant cakes were decreased. As well, the sensory properties of the cakes showed that the taste, flavor, smoothness and overall acceptability values were increased. Also, the resultant cake contained $20 \%$ sweet potato had the lowest fungi counts compared to the other cakes. Generally, either replacing white corn or sweet potato flour with white rice flour can improve the nutritional value, physical and sensory properties of rice cake produced.
\end{abstract}

Keywords: Quality attributes, nutritional value, gluten free cake, sweet potato flour, white corn flour, white rice flour

\section{INTRODUCTION}

Celiac disease is the most common food-sensitive entoropathy in humans that is triggered by the consumption of wheat gluten as well as related to protein in barley, rye and oat. The only treatment ever known for celiac disease is gluten-free diet. Most gluten-free food product on the market is rich in starch, but poor in terms of other nutrients, functional and health beneficial ingredients (Turker et al., 2016). Consequently, there is an increasing demand for glutenfree products which has augmented the research efforts as well (Rai et al., 2014; Shevkani and Singh, 2014). Ingestion of gluten containing foods by celiac patients causes atrophy of the small intestinal villi and ultimately leads to several symptoms such as cramping, bloating, nausea, diarrhea, anemia, fatigue, weight loss and vitamin and mineral deficiencies (Green and Cellier, 2007; Hegazy et al., 2009). Therefore, it is very important to develop gluten-free foodstuffs with high nutritional quality ingredients (Levent and Bilgiçli, 2011; Capriles et al., 2015).

Bakery products constitute one of the most consumed foods in the world. Among them, cakes are popular and are associated in the consumer's mind with a delicious sponge product with desired organoleptic characteristics (Abdellatif et al., 2010; Matsakidou et al., 2010). Cake batter is a complex emulsion and foam system. Flour, milk, fat, sugar, eggs and the leavening agents are the main ingredients used in its elaboration; each ingredient has an important function in the cake structure (Matsakidou et al., 2010; Turabi et al., 2010). The quality and quantity of these components are important and influence on the properties of the final product as well as the stability of quality during shelf life (Al-Dmoor, 2013). Currently utilized gluten-free flours include corn, potato, sweet potato, rice flour and starches, used as base flours due to their bland flavor and neutral effects on baked products. These flours and starches usually tend to be low in their nutritional values and have very minimal structure-building potential (O'Shea et al., 2014). White or polished rice and corn are the main ingredients, due to their abundance, low cost and high expansion capacity (Gimènez et al., 2013). However, white rice is low in fiber and has relatively poor technological properties (Marti et al., 2010). Rice flour gives rice pound cakes a rough and crumble texture. Although the hydrocolloids and gums are the best sources for increasing moistness, there are not many studies on the interaction between rice flour and their carbohydrates (Jeong et al., 2013).

Sweet potato (Ipomoea batatas L.) is an important alternative source of carbohydrates and attains fourth place after rice, corn and cassava (Zuraida, 2003; Kamal et al., 2013). Sweet potato has high nutrient, $\beta$-carotene and anthocyanin contents and has beneficial effects on human health such as improving the immunity and reduces the susceptibility of body to various ailments like cancer and muscular degenerations (Antonio et al., 2011; Pasha et al., 2015). Sweet potato flour can be added as a natural sweetener, color and flavor to processed food products. It can also serve as a source of energy, nutrients, minerals and contributes to the daily nutrient needs for $\beta$-carotene, thiamin, iron, vitamin $C$, and protein. Sweet potato flour provides $14-28 \%$ of the dietary reference intake (DRI) for magnesium and $20-39 \%$ of potassium (Van Hal, 2000). Sweet potatoes are rich in dietary fiber, ascorbic acid, folic acid and minerals (ILSI, 2008). Sweet potato recognized as a low glycemic index (GI) food with a $\mathrm{GI}<55$, suggesting its use as a food for diabetics (Bjorck et al., 2000). Orange and purple-fleshed sweet potato flours are viable for preparation of food products, mainly for baking. The sweet potato flours showed interesting index of water absorption, index of fat absorption and swelling power, which suggests a great technological quality and viability of their incorporation 
in several kinds of food products (Rodrigues et al., 2016). Sweet potato flour (even for up to $20 \%$ ) is used as a dough conditioner for bread, biscuit, and cake processing, as well as gluten-free pancake preparation (Shih et al., 2006). It helps in making a good baking product with increased economic value (Matter, 2015). It could be very valuable in decision making for industries that want to take nutritional advantages of sweet potato flour as an alternative or supplement to cereal flours. Sweet potato flour could be useful in the manufacture of highly nutritious cookies (Srivastava et al., 2012). Bakery products include various ingredients such as cereal flour, cocoa powder, sugar, egg, edible oil, nuts, dried fruit, spices, which regularly contain molds. These microorganisms on cakes can come from the air, contaminated packaging materials and other sources (Kocic-Tanackov et al., 2013; Nakhchian et al., 2014). Furthermore, dietary fiber from the root of sweet potato showed an inhibitory effect against the growth of food-borne bacteria (Mbaeyi-Nwaoha and Emejulu, 2013). Also, the total number of molds of cakes from the market and homemade were up to $9 \times 10^{2} \mathrm{CFU} / \mathrm{g}$ (Kocic-Tanackov et al., 2013).

Hence, the purpose of this study was to study the quality attributes as chemical composition, physical and sensory properties of two gluten free rice cakes. The first one as affected by white rice flour substitutions by white corn at ratio $0,17,33,50,67$ and $83 \%$. And the second one as affected by white rice flour substitutions by sweet potato at ratio $0,10,15$ and $20 \%$ in rice cake that contained (1:1) white rice to white corn flour.

\section{MATERIALS AND METHODS}

\section{MATERIALS}

White rice flour and white corn flour from (Zamzam Packaging Food, Mokattam, Cairo, Egypt), fresh orange sweet potato tuber, salt, full fat milk powder, sugar, baking powder, vanilla, Arabic gum, hens eggs and butter were purchased from local markets (Aswan government, Egypt).

Molds and yeasts agar CM0920 (Oxoid, Basingstoke, Hampshire, UK) was obtained from Beta Company, Mansoura, Egypt.

\section{METHODS}

\section{Preparation of sweet potato flour}

The orange sweet potato tubers were washed, dried, and weighed, hand-peeled, shredded and sliced. Sweet potato slices were dried by using an electric oven with an air fan (Indeset 6-EM-IN-02, Italy) at $60^{\circ} \mathrm{C}$ for about 18 hours. The dehydrated sweet potatoes were milled by house mincer (Moulinex, LM207041 Super Blender, France). The flours were packed in polyethylene bags and kept at $4 \pm 1{ }^{\circ} \mathrm{C}$ until analysis or for further use in the preparation of cakes.

\section{Formula of rice cake samples}

Cake batter samples were prepared as formula given in Table (1) according to AACC (2000). The butter was melted thoroughly, sugar and salt were added then mixed vigorously. The whole egg was mixed with vanillia and whipped until got puff and smooth likecream texture. Composite flour and other dry ingredients and water were mixed individually. This mixture was mixed gently until got homogenous dough using a hand mixer (Moulinex ABM11A30, France) at low speed for 2 minutes. Part of the batter was separated for analyzed. For the preparation of the cakes, $400 \mathrm{~g}$ of the batter were placed in a baking pan (diameter $17 \times 14$ $\mathrm{cm}$ ) and baked at $180^{\circ} \mathrm{C}$ for $45 \mathrm{~min}$ in an oven with air fan (Universal Gas, model Italian PR 6106, Egypt). The cakes were packaged in polyethylene bags and stored at room temperature for $2 \mathrm{~h}$ and then analyzed.

\section{Dough properties}

Specific gravities of the cake batter were calculated by dividing the weight of a certain volume of cake batter to the weight of the same volume of distilled water as described by Turabi et al. (2008).

\section{Nutritional value of cake samples}

Moisture, protein, ash and fat of flour and its cake samples were determined according to the methods described by AOAC (2005). Total carbohydrates were calculated by difference.

\section{Physical evaluation of cakes}

The height, length and width of the rectangular shaped cakes were measured with a vernier caliper. Weight was determined by the digital weighing balance. Volume of cake was calculated as length $\times$ width $\times$ height. Density was calculated as volume / weight as described by Akubor and Ishiwu (2013). Baking loss was calculated by weighing cake before and after baking the difference in weight was averaged and reported as a percentage of baking loss as described by Sumnu et al. (2005).

\section{Sensory properties}

All gluten free cake samples were evaluated for color, taste, flavor, distributed pores, smoothness and overall acceptability by panelists composed of 20 graduate students from Home Economics Department, Faculty of Specific Education, Aswan University. Sensory evaluation was carried out according to the method of AACC (2000) by recommending the following score (10) excellent, (9) very good, (8) good, (7) medium, (6) fair, (5) poor, (4) very poor and (3) extremely poor.

\section{Fungi count}

Mold and yeast counts of rice-sweet potato cake samples were counted after 0,7 and 12 days of storage according to the method described by Oxoid Manual (1982). After sterilizing the medium at $121^{\circ} \mathrm{C}$ for 15 minutes. Plates after inoculation were incubated at $37^{\circ} \mathrm{C}$ for 72 hours.

\section{Statistical analysis}

All data were analyzed using the Statistical Package for Social Science (SPSS) version 17.00 (SPSS Inc., Chicago, IL, USA) to perform an ANOVA according to SPSS (2008). The means of treatments were considered statistically significant at 5\% level $(P<0.05)$, using Duncan test and the results were expressed as means \pm standard deviation (SD) according to Duncan (1955). 
Table (1): Formulation of rice-white corn and rice-sweet potato cake samples

\begin{tabular}{|c|c|c|c|c|c|c|c|c|c|c|}
\hline \multirow[t]{2}{*}{ Ingredient (g) } & \multicolumn{7}{|c|}{ Rice-white corn cake } & \multicolumn{3}{|c|}{ Rice-sweet potato cake } \\
\hline & Rice & WCF & $\begin{array}{c}17 \% \\
\text { WCF }\end{array}$ & $\begin{array}{l}33 \% \\
\text { WCF }\end{array}$ & $\begin{array}{c}50 \% \\
\text { WCF }\end{array}$ & $\begin{array}{c}67 \% \\
\text { WCF }\end{array}$ & $\begin{array}{l}83 \% \\
\text { WCF }\end{array}$ & $\begin{array}{l}10 \% \\
\text { SPF }\end{array}$ & $\begin{array}{l}15 \% \\
\text { SPF }\end{array}$ & $\begin{array}{l}20 \% \\
\text { SPF }\end{array}$ \\
\hline White rice flour & 150 & - & 125 & 100 & 75 & 50 & 25 & 60 & 52.5 & 45 \\
\hline White corn flour & -- & 150 & 25 & 50 & 75 & 100 & 125 & 75 & 75 & 75 \\
\hline Sweet potato flour & -- & -- & -- & -- & -- & -- & -- & 15 & 22.5 & 30 \\
\hline Sugar & 80 & 80 & 80 & 80 & 80 & 80 & 80 & 80 & 80 & 80 \\
\hline Skimmed milk & 12 & 12 & 12 & 12 & 12 & 12 & 12 & 12 & 12 & 12 \\
\hline Arabic gum & 2 & 2 & 2 & 2 & 2 & 2 & 2 & 2 & 2 & 2 \\
\hline Salt & 1 & 1 & 1 & 1 & 1 & 1 & 1 & 1 & 1 & 1 \\
\hline Baking powder & 5.5 & 5.5 & 5.5 & 5.5 & 5.5 & 5.5 & 5.5 & 5.5 & 5.5 & 5.5 \\
\hline Vanillia & 0.5 & 0.5 & 0.5 & 0.5 & 0.5 & 0.5 & 0.5 & 0.5 & 0.5 & 0.5 \\
\hline Butter & 40 & 40 & 40 & 40 & 40 & 40 & 40 & 40 & 40 & 40 \\
\hline Hen egg (whole, fresh) & 60 & 60 & 60 & 60 & 60 & 60 & 60 & 60 & 60 & 60 \\
\hline Water & 65 & 65 & 65 & 65 & 65 & 65 & 65 & 65 & 65 & 65 \\
\hline
\end{tabular}

WRF: White rice flour; WCF: White corn flour; SPF: Sweet potato flour

\section{RESULTS AND DISCUSSIONS}

Chemical composition of white rice, white corn and sweet potato flour

Data in Table (2) showed the chemical composition of white rice, white corn and orange sweet potato flour on dried weight basis. The results showed that the white corn flour had the highest contents of moisture, protein and fat, but it had the lowest content of carbohydrates compared to white rice. Also, sweet potato flour had the highest contents of ash and fiber compared to white corn and white rice flours.

The results of chemical composition of white rice flour were in line with confirmed those of Qin et al. (2016) and Gadallah (2017). The chemical composition of white corn flour was in harmony with those of Gwirtz and Garcia-Casal (2014). Moreover, the chemical composition of dried sweet potato flour was contracted with those of Mohy Eldin (2010) and Rodrigues et al. (2016).

Table (2): Chemical composition of white rice, white corn and sweet potato flour (mean $\pm \mathrm{SD}$, on dry weight)

\begin{tabular}{|c|c|c|c|c|c|c|}
\hline Constituents & $\begin{array}{c}\text { Moisture } \\
(\%)\end{array}$ & $\begin{array}{c}\text { Protein } \\
(\%)\end{array}$ & $\begin{array}{l}\text { Fat } \\
(\%)\end{array}$ & $\begin{array}{l}\text { Ash } \\
(\%)\end{array}$ & $\begin{array}{l}\text { Fiber } \\
(\%)\end{array}$ & $\begin{array}{c}\text { Carbohydrate } \\
(\%)\end{array}$ \\
\hline White rice flour & $8.59 \pm 0.04 c$ & $6.21 \pm 0.03 b$ & $1.22 \pm 0.02 \mathrm{c}$ & $0.33 \pm 0.01 \mathrm{c}$ & $0.8 \pm 0.02 \mathrm{c}$ & $92.24 \pm 0.06 \mathrm{a}$ \\
\hline White corn flour & $10.95 \pm 0.07 \mathrm{a}$ & $11.04 \pm 0.05 \mathrm{a}$ & $3.22 \pm 0.02 \mathrm{a}$ & $1.89 \pm 0.08 b$ & $4.25 \pm 0.05 b$ & $83.85 \pm 0.09 c$ \\
\hline $\begin{array}{l}\text { Dried sweet } \\
\text { potato flour }\end{array}$ & $9.78 \pm 0.04 b$ & $4.32 \pm 0.03 c$ & $1.39 \pm 0.01 b$ & $5.61 \pm 0.04 \mathrm{a}$ & $9.27 \pm 0.03 \mathrm{ba}$ & $88.68 \pm 0.05 b$ \\
\hline
\end{tabular}

Chemical composition of rice-white corn cake samples (on dry weight)

Data in Table (3) showed the effect of different levels of white corn flour (WCF) on chemical composition of rice cake on dried weight basis. The results showed that the white corn cake sample had the highest contents of moisture, protein, fat, ash and fiber. But, it had the lowest carbohydrates content compared to rice cake and its samples. So, moisture, protein, fat, ash and fiber contents significantly increased by increasing white corn flour level in rice-white corn cake samples. 
Table (3): Chemical composition of rice-white corn cake samples (mean $\pm \mathrm{SD}$, on dry weight)

\begin{tabular}{lcccccc}
\hline Constituents & $\begin{array}{c}\text { Moisture } \\
(\%)\end{array}$ & $\begin{array}{c}\text { Protein } \\
(\%)\end{array}$ & $\begin{array}{c}\text { Fat } \\
(\%)\end{array}$ & $\begin{array}{c}\text { Ash } \\
(\%)\end{array}$ & $\begin{array}{c}\text { Fiber } \\
(\%)\end{array}$ & $\begin{array}{c}\text { Carbohydrate } \\
(\%)\end{array}$ \\
\hline Rice cake & $27.5 \pm 0.09 \mathrm{e}$ & $6.98 \pm 0.07 \mathrm{e}$ & $18.85 \pm 0.03 \mathrm{~g}$ & $0.99 \pm 0.05 \mathrm{~g}$ & $0.50 \pm 0.06 \mathrm{~g}$ & $73.18 \pm 0.07 \mathrm{a}$ \\
$\begin{array}{l}\text { White corn } \\
\text { cake }\end{array}$ & $28.23 \pm 0.03 \mathrm{a}$ & $9.38 \pm 0.09 \mathrm{a}$ & $20 \pm 0.06 \mathrm{a}$ & $1.78 \pm 0.07 \mathrm{a}$ & $1.54 \pm 0.03 \mathrm{a}$ & $68.84 \pm 0.05 \mathrm{e}$ \\
$\mathbf{1 7 \%}$ WCF & $27.56 \pm 0.05 \mathrm{de}$ & $7.37 \pm 0.05 \mathrm{edc}$ & $18.97 \pm 0.07 \mathrm{f}$ & $1.12 \pm 0.04 \mathrm{f}$ & $0.68 \pm 0.04 \mathrm{f}$ & $72.54 \pm 0.02 \mathrm{a}$ \\
$\mathbf{3 3 \%}$ WCF & $27.65 \pm 0.06 \mathrm{~cd}$ & $7.77 \pm 0.04 \mathrm{ed}$ & $19.23 \pm 0.04 \mathrm{e}$ & $1.27 \pm 0.03 \mathrm{e}$ & $0.85 \pm 0.07 \mathrm{e}$ & $71.73 \pm 0.06 \mathrm{~b}$ \\
$\mathbf{5 0} \% \mathbf{W C F}$ & $27.74 \pm 0.07 \mathrm{c}$ & $8.18 \pm 0.06 \mathrm{bdc}$ & $19.37 \pm 0.02 \mathrm{~d}$ & $1.39 \pm 0.07 \mathrm{~d}$ & $1.03 \pm 0.05 \mathrm{~d}$ & $71.06 \pm 0.03 \mathrm{c}$ \\
$\mathbf{6 7 \%} \mathbf{W C F}$ & $27.94 \pm 0.06 \mathrm{~b}$ & $8.58 \pm 0.05 \mathrm{ba}$ & $19.63 \pm 0.07 \mathrm{c}$ & $1.52 \pm 0.05 \mathrm{c}$ & $1.19 \pm 0.03 \mathrm{c}$ & $70.27 \pm 0.05 \mathrm{c}$ \\
$\mathbf{8 3 \%}$ WCF & $28.14 \pm 0.05 \mathrm{a}$ & $8.98 \pm 0.04 \mathrm{ba}$ & $19.77 \pm 0.03 \mathrm{~b}$ & $1.65 \pm 0.08 \mathrm{~b}$ & $1.364 \pm 0.07 \mathrm{~b}$ & $69.6 \pm 0.08 \mathrm{~d}$ \\
\hline
\end{tabular}

Means in the same column with different superscript differed significantly at $\mathrm{p}<0.05$

On the other hand, carbohydrate contents were decreased by increasing the level of white corn flour. All these results were due to difference in chemical composition between white rice and white corn flour as shown in Table (2). These results were confirmed with those of Guy_(2012) who reported that the major chemical compositions that enhance the water absorption capacities of flours are proteins and carbohydrates since these constituents contain hydrophilic parts such as polar or charged side chains. As well, these results were confirmed with those of Islam et al. (2007) and Begum et al. (2013). Also, the results were agreed with those of Olkiewicz and Moch (2008) they reported that raw materials are the most important moderator of chemical and rheological properties of the final products.

\section{Physical properties of rice-white corn batter and its cake samples}

Physical properties of batter as specific gravity is a very important physical property affecting the product quality since it represents retain of the small bubbles, which are initially incorporated into the batter during the mixing time (Turabi et al., 2008). Specific gravity is a measurement of air incorporated into a cake batter during mixing (Marina et al., 2016). Moreover, baking loss is described as a process in which gas is produced and vapor pressure increases due to the expansion of liquids when heat permeates the batter in the baking process. If gas escapes, cakes become damaged. Thus, baking loss and its effects on shelf-life are of concern for the structural transformation of cakes (Kim et al., 2012).

The effect of replacing white rice by white corn flour on physical properties of cake batter and its resultant cake is presented in Table (4). The specific gravities of cake batter were decreased by increasing the levels of white corn flour. So, it has a direct relation to the volume, tenderness, and texture of the finished cake. Low specific gravity is associated with good aeration of batter (Levent and Bilgiçli, 2011).

The baking loss of rice cake had the highest value compared to white corn cake. Also, the baking loss values of rice-white corn cake samples were decreased by increasing white corn flour levels compared to rice cake sample. These results might be due to white corn flour had higher contents of protein and fiber compared to white rice flour, which has high hydration properties comparable to white rice flour. These results were in harmony with those of Bonder and Sieg (2009), they found that certain functions of dietary fiber, such as increasing water and fat absorption. Also, these results might be due to the high protein content of white corn flour and consequently high rehydration properties compared to rice flour (Hassan, 2002).

Table (4): Physical properties (mean $\pm \mathrm{SD}$ ) of rice-white corn batter and its cake samples

\begin{tabular}{|c|c|c|c|c|c|}
\hline Constituents & $\begin{array}{l}\text { Specific gravities } \\
\left(\mathrm{g} / \mathrm{cm}^{3}\right)\end{array}$ & Baking loss (\%) & $\begin{array}{l}\text { Volume } \\
\left(\mathrm{cm}^{3}\right)\end{array}$ & $\begin{array}{c}\text { Weight } \\
\text { (g) }\end{array}$ & $\begin{array}{l}\text { Specific volume } \\
\left(\mathrm{cm}^{3} / \mathrm{g}\right)\end{array}$ \\
\hline Rice & $1.15 \pm 0.01 \mathrm{a}$ & $9.11 \pm 0.02 \mathrm{a}$ & $612.5 \pm 0.50 \mathrm{~g}$ & $363.56 \pm 0.51 \mathrm{~d}$ & $1.68 \pm 0.00 \mathrm{~g}$ \\
\hline White corn & $1.1 \pm 0.01 \mathrm{~d}$ & $7.93 \pm 0.01 \mathrm{~g}$ & $884.45 \pm 0.51 \mathrm{a}$ & $368.28 \pm 0.95 \mathrm{a}$ & $2.40 \pm 0.01 \mathrm{a}$ \\
\hline $17 \%$ WCF & $1.135 \pm 0.001 \mathrm{ba}$ & $8.92 \pm 0.01 b$ & $700.7 \pm 0.61 \mathrm{f}$ & $364.32 \pm 1.14 \mathrm{~d}$ & $1.92 \pm 0.01 \mathrm{f}$ \\
\hline $33 \% \mathrm{WCF}$ & $1.125 \pm 0.001 b c$ & $8.88 \pm 0.01 \mathrm{c}$ & $774.2 \pm 0.8 \mathrm{e}$ & $364.48 \pm 0.50 \mathrm{~d}$ & $2.12 \pm 0.00 \mathrm{e}$ \\
\hline $50 \%$ WCF & $1.123 \pm 0.001 b c$ & $8.75 \pm 0.01 d$ & $812 \pm 1 d$ & $365 \pm 0.5 \mathrm{~cd}$ & $2.22 \pm 0.00 \mathrm{~d}$ \\
\hline $67 \% \mathrm{WCF}$ & $1.11 \pm 0.01 \mathrm{dc}$ & $8.43 \pm 0.01 \mathrm{e}$ & $850 \pm 1.03 \mathrm{c}$ & $366.28 \pm 1.44 b c$ & $2.32 \pm 0.01 c$ \\
\hline $83 \%$ WCF & $1.1 \pm 0.03 \mathrm{~d}$ & $8.2 \pm 0.03 f$ & $862.4 \pm 0.53 b$ & $367.2 \pm 0.53 \mathrm{ba}$ & $2.35 \pm 0.00 \mathrm{~b}$ \\
\hline
\end{tabular}


Rice cake had lower volume value compared to white corn cake, so the volume values of rice-white corn cake samples were increased by increasing the levels of white corn flour. So, specific volume values were increased. These results might be due to increasing network protein by increasing protein content and results to increase fiber as presented in Table (3). These results were agreed with those of Marina et al. (2016) they reported that specific volume of bake cake indicates the amount of air that can remain in the final product. Besides, the results were in line with those of Salama et al. (2013) they found that the higher specific volume shows higher gas retention and higher expansion of cake.

Table (5): Sensory properties (mean \pm SD) of rice-white corn cake samples

\begin{tabular}{lcccccc}
\hline Cake samples & Color (10) & Taste (10) & Flavor (10) & $\begin{array}{c}\text { Distributed } \\
\text { pores (10) }\end{array}$ & $\begin{array}{c}\text { Smoothness } \\
\text { (10) }\end{array}$ & $\begin{array}{c}\text { Overall } \\
\text { acceptability (10) }\end{array}$ \\
\hline Rice & $7.0 \pm 0.13 \mathrm{e}$ & $8 \pm 0.12 \mathrm{~d}$ & $8 \pm 0.18 \mathrm{a}$ & $9 \pm 0.17 \mathrm{a}$ & $8 \pm 0.18 \mathrm{a}$ & $7.2 \pm 0.16 \mathrm{c}$ \\
White corn & $8.5 \pm 0.14 \mathrm{~b}$ & $7.84 \pm 0.20 \mathrm{e}$ & $7 \pm 0.13 \mathrm{e}$ & $8 \pm 0.14 \mathrm{e}$ & $7.15 \pm 0.18 \mathrm{~d}$ & $6.5 \pm 0.15 \mathrm{f}$ \\
$\mathbf{1 7 \%}$ WCF & $7.86 \pm 0.09 \mathrm{~d}$ & $8.2 \pm 0.14 \mathrm{c}$ & $7.9 \pm 0.12 \mathrm{~b}$ & $8.8 \pm 0.23 \mathrm{~b}$ & $7.9 \pm 0.18 \mathrm{a}$ & $7 \pm 0.2 \mathrm{~d}$ \\
$\mathbf{3 3 \%}$ WCF & $8.28 \pm 0.12 \mathrm{c}$ & $8.5 \pm 0.23 \mathrm{~b}$ & $7.8 \pm 0.15 \mathrm{~b}$ & $8.8 \pm 0.20 \mathrm{~b}$ & $7.7 \pm 0.20 \mathrm{~b}$ & $7.7 \pm 0.28 \mathrm{~b}$ \\
$\mathbf{5 0 \%}$ WCF & $8.52 \pm 0.33 \mathrm{a}$ & $8.7 \pm 0.21 \mathrm{a}$ & $7.6 \pm 0.22 \mathrm{c}$ & $8.5 \pm 0.14 \mathrm{c}$ & $7.6 \pm 0.22 \mathrm{bc}$ & $8.1 \pm 0.17 \mathrm{a}$ \\
$\mathbf{6 7 \%}$ WCF & $8.68 \pm 0.27 \mathrm{a}$ & $8 \pm 0.17 \mathrm{~d}$ & $7.28 \pm 0.23 \mathrm{~d}$ & $8.17 \pm 0.12 \mathrm{~d}$ & $7.5 \pm 0.23 \mathrm{c}$ & $7.94 \pm 0.21 \mathrm{a}$ \\
$\mathbf{8 3 \%}$ WCF & $8.82 \pm 0.21 \mathrm{a}$ & $7.93 \pm 0.19 \mathrm{e}$ & $7.11 \pm 0.15 \mathrm{e}$ & $8.07 \pm 0.13 \mathrm{ed}$ & $7.3 \pm 0.15 \mathrm{~d}$ & $7.36 \pm 0.17 \mathrm{c}$ \\
\hline
\end{tabular}

Means in the same column with different superscript differed significantly at $\mathrm{p}<0.05$

\section{Sensory properties of rice-white corn cake samples}

Data found in Table (5) showed the effect of different levels of white corn flour on sensory properties of rice-white corn cake samples. The results displayed that the white corn cake had the lower sensory properties compared to rice cake. These results were agreed with Mekhael (2017) who found that rice cake gave higher sensory evaluation results for the fresh cake and also after prolonged shelf time compared to corn cake. Furthermore, the colour and scores of cake samples were gradually increased by increasing levels of white corn flour. Also, the taste was increased by increasing levels of white corn flour, but it was decreased in cake contained $83 \%$ white corn flour. The rice cake had the highest flavor scores compared to white corn cake and other cake samples also, the taste score was decreased by increasing white corn flour. Rice cake had the highest smoothness scores compared to other cake samples. So, smoothness scores were decreased by increasing levels of white corn flour. These results might be due to white rice flour has soft taste, white colour, mild flavor and pale appearance (López et al., 2004). Also, corn flour has a stronger flavor and its color is rather yellowish, which will influence the characteristics of the final product (Gómez and Sciarini, 2015). Furthermore, rice cake had the highest scores of distributed pores compared to other cake samples, but they were decreased by increasing levels of white corn flour. Overall acceptability of rice-white corn cake samples were more than that of white corn or rice cake, these results might be due to difference between chemical composition and physical properties of white rice flour and functional characteristics which effect on final products. These results were in agreement with those of Bolade et al. (2002) they found that the quality and general acceptability of a cereal food product is reported to be influenced by the physical and chemical properties of the cereal from which it is produced. These properties may be modified through chemical, physical and enzymatic processes to obtain desired functional characteristics.

Table (6): Chemical composition of rice-sweet potato cake samples (mean $\pm \mathrm{SD}$, on dry weight)

\begin{tabular}{lcccccc}
\hline $\begin{array}{l}\text { Cake } \\
\text { sample }\end{array}$ & Moisture (\%) & $\begin{array}{c}\text { Protein } \\
\mathbf{( \% )}\end{array}$ & $\begin{array}{c}\text { Fat } \\
\mathbf{( \% )}\end{array}$ & $\begin{array}{c}\text { Ash } \\
\mathbf{( \% )}\end{array}$ & $\begin{array}{c}\text { Fiber } \\
(\%)\end{array}$ & $\begin{array}{c}\text { Carbohydrate } \\
(\%)\end{array}$ \\
\hline $\mathbf{0 \%}$ SPF & $27.74 \pm 0.07 \mathrm{~b}$ & $8.18 \pm 0.06 \mathrm{a}$ & $19.37 \pm 0.02 \mathrm{~d}$ & $1.39 \pm 0.07 \mathrm{~d}$ & $1.03 \pm 0.05 \mathrm{~d}$ & $71.06 \pm 0.03 \mathrm{a}$ \\
$\mathbf{1 0 \%}$ SPF & $27.86 \pm 0.04 \mathrm{~b}$ & $7.9 \pm 0.03 \mathrm{~b}$ & $20 \pm 0.02 \mathrm{c}$ & $1.59 \pm 0.05 \mathrm{c}$ & $1.2 \pm 0.02 \mathrm{c}$ & $70.51 \pm 0.05 \mathrm{~b}$ \\
$\mathbf{1 5 \%}$ SPF & $28.0 \pm 0.09 \mathrm{a}$ & $7.62 \pm 0.01 \mathrm{c}$ & $20.6 \pm 0.03 \mathrm{~b}$ & $1.82 \pm 0.03 \mathrm{~b}$ & $1.43 \pm 0.02 \mathrm{~b}$ & $69.96 \pm 0.08 \mathrm{c}$ \\
$\mathbf{2 0 \%}$ SPF & $28.11 \pm 0.10 \mathrm{a}$ & $7.45 \pm 0.03 \mathrm{~d}$ & $21.2 \pm 0.02 \mathrm{a}$ & $2 \pm 0.08 \mathrm{a}$ & $1.66 \pm 0.03 \mathrm{a}$ & $69.35 \pm 0.06 \mathrm{~d}$ \\
\hline
\end{tabular}


Chemical composition of rice-sweet potato cake samples (on dry weight)

Data presented in Table (6) showed the effect of different levels of sweet potato flour on the chemical composition of rice-sweet potato cake samples. The moisture, fat, ash and fiber were increased, but the protein and carbohydrate contents were decreased as sweet potato flour was increased. These results might be due to the difference on chemical composition of sweet potato flour compared to white rice flour as found in Table (2). The result of increasing moisture and fat contents might be due to increase fiber and sugar contents of sweet potato, which have high hygroscopic nature and the higher water absorption capacity and fat in the composite flour compared to white rice flour. These results were confirmed with those of Alloush (2015) and Matter (2015) they found that increasing levels of replacing wheat flour by sweet potato flour caused increasing of moisture, ash, but protein content was decreased in cake or bread blends. Also, these results were agreed with those of Lim and Wan Rosli (2013) and Marina et al. (2016) they found that high fiber content may retain water by preventing evaporation during baking.

Table (7): Physical properties (mean $\pm \mathrm{SD}$ ) of rice-sweet potato cake samples

\begin{tabular}{lccccc}
\hline $\begin{array}{l}\text { Cake } \\
\text { sample }\end{array}$ & $\begin{array}{c}\text { Specific gravities } \\
\left(\mathbf{g} / \mathbf{c m}^{\mathbf{3}}\right)\end{array}$ & Baking loss $(\mathbf{\%})$ & $\begin{array}{c}\text { Volume } \\
\left(\mathbf{c m}^{\mathbf{3}}\right)\end{array}$ & $\begin{array}{c}\text { Wight } \\
(\mathbf{g})\end{array}$ & $\begin{array}{c}\text { Specific volume } \\
\left(\mathbf{c m}^{\mathbf{3}} / \mathbf{g}\right)\end{array}$ \\
\hline $\mathbf{0 \%}$ SPF & $1.123 \pm 0.0 \mathrm{a}$ & $8.75 \pm 0.04 \mathrm{a}$ & $812 \pm 0.92 \mathrm{a}$ & $365 \pm 0.87 \mathrm{~d}$ & $2.22 \pm 0.01 \mathrm{a}$ \\
$\mathbf{1 0 \%} \mathbf{S P F}$ & $1.112 \pm 0.0 \mathrm{~b}$ & $8.30 \pm 0.06 \mathrm{~b}$ & $776.6 \pm 0.5 \mathrm{~b}$ & $366.8 \pm 0.9 \mathrm{c}$ & $2.12 \pm 0.0 \mathrm{~b}$ \\
$\mathbf{1 5 \%}$ SPF & $1.105 \pm 0.001 \mathrm{c}$ & $7.91 \pm 0.03 \mathrm{c}$ & $756.36 \pm 0.75 \mathrm{c}$ & $368.36 \pm 0.56 \mathrm{~b}$ & $2.05 \pm 0.00 \mathrm{c}$ \\
$\mathbf{2 0 \%}$ SPF & $1.102 \pm 0.001 \mathrm{c}$ & $7.5 \pm 0.02 \mathrm{~d}$ & $744.48 \pm 0.50 \mathrm{~d}$ & $370 \pm 0.5 \mathrm{a}$ & $2.01 \pm 0.00 \mathrm{~d}$ \\
\hline
\end{tabular}

Means in the same column with different superscript differed significantly at $p<0.05$

\section{Physical properties of rice-sweet potato batter and its cake samples}

Data in Table (7) showed the effect of replacing white rice flour by sweet potato flour on physical properties of cake batter and its cake samples. The specific gravities of cake batter were decreased by increasing the levels of sweet potato flour. Also, the volume values were decreased so, the specific volume values of cake samples were deceased. These results might be due to attributed to sweet potato flour has low viscosity, so the bubbles in the batter can easily rise to the surface and are lost to the atmosphere during baking which caused collapse of the structure of the cake (Turabi et al., 2008). The baking loss values were decreased, so the weight values were increased. These results might be attributed to the high fiber content which increased the water absorption capacity of sweet potato flour. All these results were in agreement with those obtained by Alloush (2015) and Matter (2015) they found that the increasing supplementations of sweet potato flour to wheat flour lowered the loaf volume, while loaf weight was increased so, the specific volume values were deceased. These results might be due to sugars found in sweet potato which are known to delay starch gelatinization by reducing the water activity of the system and stabilizing the amorphous regions of the starch granule by interacting with starch chains. Thus, cake cannot entrap the gas bubbles leading to lower volume and harder structure (Milde et al., 2012).

Also, the results were agreed with those of Julianti et al. (2017) they found that increasing levels of replacing corn starch by sweet potato flour caused a decrease in a specific volume of pan bread because it has a lower viscosity than corn flour.

Table (8): Sensory properties (mean \pm SD) of rice-sweet potato cake samples

\begin{tabular}{lcccccc}
\hline Cake sample & $\begin{array}{c}\text { Color } \\
\mathbf{( 1 0 )}\end{array}$ & $\begin{array}{c}\text { Taste } \\
\mathbf{( 1 0 )}\end{array}$ & $\begin{array}{c}\text { Flavor } \\
\mathbf{( 1 0 )}\end{array}$ & $\begin{array}{c}\text { Distributed } \\
\text { pores } \\
\mathbf{( 1 0 )}\end{array}$ & $\begin{array}{c}\text { Smoothness } \\
\mathbf{( 1 0 )}\end{array}$ & $\begin{array}{c}\text { Overall } \\
\text { acceptability } \\
(\mathbf{1 0})\end{array}$ \\
\hline $\mathbf{0 \%}$ SPF & $8.17 \pm 0.13 \mathrm{~b}$ & $8.1 \pm 0.17 \mathrm{c}$ & $7.6 \pm 0.22 \mathrm{~d}$ & $8.5 \pm 0.14 \mathrm{~b}$ & $7.6 \pm 0.22 \mathrm{c}$ & $8.7 \pm 0.21 \mathrm{a}$ \\
$\mathbf{1 0 \%} \mathbf{S P F}$ & $8.22 \pm 0.31 \mathrm{a}$ & $8.4 \pm 0.18 \mathrm{~b}$ & $8.2 \pm 0.16 \mathrm{c}$ & $8.7 \pm 0.21 \mathrm{a}$ & $8.41 \pm 0.18 \mathrm{~b}$ & $8.7 \pm 0.22 \mathrm{a}$ \\
$\mathbf{1 5 \%} \mathbf{S P F}$ & $7.9 \pm 0.12 \mathrm{c}$ & $9 \pm 0.18 \mathrm{a}$ & $9.3 \pm 0.19 \mathrm{~b}$ & $8.5 \pm 0.09 \mathrm{~b}$ & $8.5 \pm 0.13 \mathrm{~b}$ & $8.72 \pm 0.11 \mathrm{a}$ \\
$\mathbf{2 0 \%}$ SPF & $7.5 \pm 0.11 \mathrm{~d}$ & $9.2 \pm 0.20 \mathrm{a}$ & $9.5 \pm 0.29 \mathrm{a}$ & $8.2 \pm 0.16 \mathrm{c}$ & $9 \pm 0.12 \mathrm{a}$ & $8.81 \pm 0.21 \mathrm{a}$ \\
\hline
\end{tabular}


Data in Table (8) showed the effect of replacing white rice flour by sweet potato flour on sensory properties of rice-sweet potato cake samples. The results showed that the color scores of these cake samples were gradually decreased, these results might be due to increasing the yellow color of sweet potato flour was due to the presence of carotenoid pigments (Kenny et al., 2000). Moreover, these results were in harmony with those of Matter (2015) who found that the color of the bread was significantly affected $(\mathrm{P}<0.05)$ by the addition of sweet potato flour, but the color of $15 \%, 20 \%$ substitution of the sweet potato flour, bread showed a significant decrease $(\mathrm{P}<0.05)$. On the other hand the taste, flavor, smoothness and overall acceptability scores of cake were increased by increasing the levels of sweet potato flour. Also, the cake sample that containing 20\% sweet potato flour showed the highest sensory properties compared to other rice-sweet potato cake and rice cake samples that found in Table (5). These results might be due to sweet potato flour has a natural sweetness and flavor. These results were conformed to that of Van Hal (2000). Also, these results were agreed with those of Truong et al. (2011) they reported that sweet potato (Ipomoea batatas L.) has a high nutritional value and sensory versatility. Also, these results were concordant with those of Dansby and Bovell-Benjamin (2003) and Alloush (2015) they found that the level of ingredients of cake samples recipes and preparation have been reported to affect the sensory attributes, preference and overall acceptability of the cakes.

Table (9): Fungal count (CFU/g) on stored rice-sweet potato cake samples

\begin{tabular}{lccc}
\hline Cake sample & Zero day & $\mathbf{7}$ Days & $\mathbf{1 2}$ days \\
\hline $\mathbf{0 \%}$ SPF & ND & $4.2 \times 10 \pm 2.05 \mathrm{a}$ & $5 \times 10^{2} \pm 1.1 \mathrm{a}$ \\
$\mathbf{1 0 \%}$ SPF & ND & $2.1 \times 10 \pm 1.08 \mathrm{~b}$ & $3.1 \times 10^{2} \pm 2.07 \mathrm{~b}$ \\
$\mathbf{1 5 \%}$ SPF & ND & $1.8 \times 10 \pm 1.07 \mathrm{c}$ & $2.6 \times 10^{2} \pm 3.09 \mathrm{c}$ \\
$\mathbf{2 0} \%$ SPF & ND & $1.63 \times 10 \pm 2.05 \mathrm{~d}$ & $2.13 \times 10^{2} \pm 1.05 \mathrm{~d}$ \\
\hline
\end{tabular}

ND: Not detected Means in the same column with different superscript differed significantly at $\mathrm{p}<0.05$.

\section{Fungal count on stored rice-sweet potato cake samples}

Data in Table (9) showed the effect of replacing white rice flour by sweet potato flour on fungal counts of cake samples. The results showed that there were fungi non detected at zero time. These results might be due to that raw material free from yeast and mold or baking process killed some of the microorganisms. These results were compatible with those of Tadesse et al. (2015) and Daniyan and Nwokwu (2011). Moreover, yeast and mold of rice-sweet potato cake after 7 and 12 days were lower than that of result obtained by El-Zainy et al. (2014) they found that yeast and mold of sponge cake storage at room temperature after week were $8.33 \times 10^{2} \mathrm{Cfu} / \mathrm{g}$.

On the other hand, at 7 days the fungi counts were found and were increased by increasing time of storage. Furthermore, the rice cake contained 20\% sweet potato flour had the lowest content of fungi compared to rice cake contained $0 \%$ sweet potato. These results might be due to that sweet potato has many antifungal compound effects. These results were congruent with those of Wen et al. (2016) they reported that anthocyanins from purple sweet potato (APSP) exhibited enhanced antifungal properties in the presence of food preservatives. As well, the results were contracted with those of Rangel et al. (2011) they found that orange-fleshed sweet potato flour helped reach a suitable condition for storing and transporting the sweet potato in the form of flour, thereby increasing shelf life from only a few days (fresh product) to several months, suggesting that high levels of beta-carotene are preserved by the reduction of water activity in the flour, thus adding nutritional value to the final product. Furthermore, these results were congruent with those obtained by Pasha et al. (2015) and Mohy Eldin (2010) they found that as adding sweet potato powder to white wheat pan bread the total fungi were decreased compared to control sample.

The presence of microorganisms in these cake samples may be attributed to the fact that they may have been contaminated in the cause of keeping the samples. Also, the high temperature degree of the atmosphere caused activation of microbial. These results were agreed with those of Olaoye et al. (2007) and Chinelo (2012) they reported that the baked product should however be well kept after processing in suitable packaging materials capable of preventing contamination and hence the subsequent proliferation of spoilage microorganisms.

\section{CONCLUSION}

Substituting white rice flour with white corn or sweet potato flour in gluten free rice cake samples at different levels can improve nutritional value, physical and sensory properties of the rice cake samples. All rice-white corn cake and rice-sweet potato cake samples are organoleptically acceptable. Moreover, the cake contained $20 \%$ sweet potato flour showed the highest sensory properties and lowest fungal count compared to the other rice sweet potato cake samples. 


\section{REFERENCES}

AACC (American Association of Cereal Chemists) (2000). Cereal Laboratory Method. American Association Chemists, INC. St. Paul., Minnesota USA.

Abdellatif, M. A., J. Xu and M. Singh (2010). Yeast leavened banana bread: formulation, processing, color and texture analysis. J Food Chem., 118(3): 620-626.

Akubor, P. I. and C. Ishiwu (2013). Chemical composition, physical and sensory properties of cakes supplemented with plantain peel flour. Int. J. Agric. Policy Res., 1 (4): 87-92.

Al-Dmoor, H. M. (2013). Cake flour: functionality and quality (Review). European Scientific Journal, 9(3): 166-180.

Alloush, S. A. (2015). Chemical, physical and sensory properties of sweet potato cake. Egypt. J. Agric. Res., 93(1): 101-115.

Antonio, G. C., C. Y. Takeiti, R. A. de Oliveira and K. J. Park (2011). Sweet potato: production, morphological and physicochemical characteristics and technological process. Fruit, Veg. Cereal Sci. Biotech., 5(2): 1-18.

AOAC (2005). Official methods of analysis. Association of Official Analytical Chemists. $18^{\text {th }}$ Ed. Washington, DC.

Begum, R. M., J. Uddin, M. A. Rahman and M. S. Islam (2013). Comparative study on the development of maize flour based composite bread. J. Bangladesh Agric. Univ., 11(1): $133-139$

Bjorck, I., H. Liljeberg and E. Ostman (2000). Low glycemic-index foods. Brit. J. Nutr., 83: 149155.

Bolade, M. K., M. A. Usman, A. A. Rasheed, E. L. Benson and I. Salifou (2002). Influence of hydrothermal treatment of maize grains on the quality and acceptability of tuwon masara (traditional maize gel). Food Chem., 79: 479483.

Bonder, J. M. and J. Sieg (2009). Fiber. In: Ingredient in meat products: properties, functionally and applications. Trate, R. (Ed). New York: Springer Science Business Media, LLC. Pp 83: 120.

Capriles, V. D., F. G. D. Santos and J. A. G. Areas (2015). Gluten-free bread making: improving nutritional and bioactive compounds. J. Cereal Sci., 67(1): 83-91.

Chinelo, O. E. (2012). Production and evaluation of baked and extruded snacks from blends of millet, pigeon pea and cassava cortex flour. Thesis M.Sc. Fac. Agric, Univ. Nigeria, Nsukka.

Daniyan, S. Y. and O. E. Nwokwu (2011). Enumeration of microorganisms associated with the different stages of bread production in Futmin bakery, Nigeria. Int. Res. J. Pharm., 2(7): 8891.

Dansby, M. A. and A. C. Bovell-Benjamin (2003). Sensory characterization of a eat sweet potato breakfast cereal by descriptive analysis. J. Food Sci., 68(2): 706- 709.

Duncan, D. (1955). Multiple range and multiple F test. Biometric, 11: 1-42. Edition ASSOC. Office. Anal. Chem. Arlington.

El-Zainy, A. R. M., H. F. Aboul-Anean, L. A. Shelbaya and E. M. M. Ramadan (2014). Effect of edible coating with cinnamon oil on the quality of cake. Middle East J. Appl. Sci., 4(4): 1171-1186.

Gadallah, M. G. E. (2017). Rheological, organoleptical and quality characteristics of gluten-free rice cakes formulated with sorghum and germinated chickpea flours. Food and Nutr. Sci., 8: 535-550.

Gimènez, M. A., R. J. Gonzalez, J. Wagnerc, R. Torres, M. O. Iobo and N. C. Samman (2013). Effect of extrusion conditions on physicochemical and sensorial properties of corn-broad beans (Vicia faba) spaghetti type pasta. Food Chem., 136(2): 538-545.

Gómez, M. and L. S. Sciarini (2015). Gluten-free bakery products and pasta. In: Advances in the understanding of gluten related pathology and the evolution of gluten-free foods. Arranz, E.; Fernández-Bañares, F.; Rosell, CM.; Rodrigo, L. and Peña, AS, editors Barcelona, Spain: Omnia Science, p. 565-604.

Green, P. H. and C. Cellier (2007). Celiac disease. N Engl J. Med., 357(17): 1731-1743.

Guy, E. (2012). Nutrient composition and functional properties of bean flours of three soya bean varieties from Ghana. Afr. J. Food Sci. Technol., 3(8): 176-181.

Gwirtz, J. A. and M. N. Garcia-Casal (2014). Processing maize flour and corn meal food products. Ann. N.Y. Acad. Sci., 1312(12): 66-75.

Hassan, F. R. H. (2002). Studies on the bioconversion of some agricultural wastes using Pleurotus and Agricus mushrooms. Ph.D. Thesis, Fac. Agric. Cairo Univ. Egypt.

Hegazy, A. I., M. S. Ammar and M. I. Ibrahium (2009). Production of Egyptian gluten-free bread. World J. Dairy and Food Sci., 4(2): 123-128.

ILSI (International Life Sciences Institute) (2008). Nutritionally improved sweet potato. Washington, D.C.: IntI. Life Sciences Inst. Available from: http://www3.interscience.wiley. com/cgi-bin/fulltext/119423793/PDFSTART). Access September 01, 2008.

Islam, T., A. Chowdhury, M. Islam and S. Islam (2007). Standardization of bread preparation from soy flour. Int. J. Sustain. Crop Prod., 2(6): 15-20.

Jeong, S., W. S. Kang and M. Shin (2013). Improvement of the quality of gluten-free rice pound cake using extruded rice flour. Food Sci. Biotechnol., 22(1): 173-180.

Julianti, E., H. Rusmarilin, Ridwansyah and E. Yusraini (2017). Functional and rheological properties of composite flour from sweet potato, maize, soybean and xanthan gum. J. Saudi Society Agric. Sci., 16: 171-177. 
Kamal, M. S., M. N. Islam and M. G. Aziz (2013). Effect of sweet potato flour of two local varieties on quality of breads. J. Bangladesh Agric. Univ., 11(2): 301-306.

Kenny, S., W. Karina, S. Catherine and A. Elke (2000). Incorporation of dairy ingredients into wheat bread: Effects on dough rheology and bread quality. Eur. Food Res. Technol., 210(1): 391396.

Kim, J. H., H. J. Lee, H. S. Lee, E. J. Lim, J. Y. Imm and H. J. Suh (2012). Physical and sensory characteristics of fibre-enriched sponge cakes made with Opuntia humifusa. LWT-Food Sci. Technol., 47: 478-484.

Kocic-Tanackov, S., G. Dimic, J. Levic, L. Mojovic and J. Pejin (2013). Contamination of cakes with toxigenic molds. J. Nat. Sci., Matica Srpska Novi Sad., 124: 213-226.

Levent, H. and N. Bilgiçli (2011). Effect of gluten-free flours on physical properties of cakes. J. Food Sci. Eng., 1: 354-360.

Lim, J. Y. and W. I. Wan Rosli (2013). The ability of Zea mays ear (young corn) powder in enhancing nutritional composition and changing textural properties and sensory acceptability of yeast bread. Int. Food Res. J., 20: 799-804.

López, A. C. B., A. J. G. Pereira and G. R. Junqueira (2004). Flour mixture of rice flour, corn and cassava starch in the production of gluten-free white bread. Brazilian Archives of Biology and Tech., 47(1): 63-70.

Marina, A. M., A. R. Nurhanan, W. I. Wan Rosli and O. Nurul Ain (2016). Physical properties and microstructure of butter cake added with Persea americana puree. Sains Malaysiana, 45(7): 1105-1111.

Marti, A., K. Seetharaman and M. A. Pagani (2010). Rice-based pasta: A comparison between conventional pasta-making and extrusioncooking. J. Cereal Sci., 52: 404-409.

Matsakidou, A., G. Blekas and A. Paraskevopoulou (2010). Aroma and physical characteristics of cakes prepared by replacing margarine with extra virgin olive oil. LWT- Food Science and Technology, 43(6): 949-957.

Matter, A. A. (2015). Quality evaluation of wheat-sweet potato composite flours and their utilization in bread making. Int. J. Adv Res. Biol. Sci., 2(11): 294-303.

Mbaeyi-Nwaoha, I. E. and V. N. Emejulu (2013). Evaluation of phytochemical composition and antimicrobial activity of sweet potato (Ipomoea batatas) leaf. Pak. J. Nutr., 12(6): 575-586

Mekhael, E. K. G. (2017). Production of cake and biscuit using some improvers for celiac disease patients. Ph.D. Thesis, Fac. Agric. Cairo Univ. Egypt.

Milde, L., L. Ramallo and M. Puppo (2012). Gluten-free bread based on tapioca starch: Texture and sensory studies. Food Bioprocess Technol., 5: 888-896.
Mohy Eldin, E. A. F. (2010). Studies on bread fortification with sweet potato. M.Sc. Thesis, Fac. Specific Education, Mansoura Univ. Egypt.

Nakhchian, H., F. T. Yazdi, S. A. Mortazavi and M. Mohebbi (2014). Isolation, identification and growth's comparison f mold types in a cake factory environment and final products. Int. J. Adv. Biol. Biom. Res., 2(8): 2505-2517.

O'Shea, N., E. Arendt and E. Gallagher (2014). State of the art in gluten-free research. J. Food Sci., 79(6): 1067-1076.

Olaoye O. A., A. A. Ondude and C. O. Oladoye (2007). Breadfruit flour in biscuit making: effects on product quality. Afr. J. Food Sci., (1): 20-23

Olkiewicz, M. and P. Moch (2008). Effect of raw material formulation on basic composition and rheological properties of a model product of mortadella type. Acta Agrophysica, 11(1): 159-173.

Oxoid Manual (1982). Oxoid manual of culture media ingredient and other laboratory services. $5^{\text {th }}$ Ed. Oxoid Limited.

Pasha, I., M. R. Khan, A. Ali, M. F. J. C. Chughtai, S. Ahmad and M. A. Nasir (2015). Physicochemical and microbial properties of bread supplemented with sweet potato flour. Pak. J. Food Sci., 25(1): 26-36.

Qin, Y., C. Liu, S. Jiang, J. Cao, L. Xiong and Q. Sun (2016). Functional properties of glutinous rice flour by dry-heat treatment. PLOS ONE., 11(8): 1371- 1381 .

Rai, S., A. Kaur and B. Singh (2014). Quality characteristics of gluten free cookies prepared from different flour combinations. J. Food Sci. Technol., 51: 785-789.

Rangel, C. N., E. M. M. da Silva, L. Salvador, R. Figueiredo, E. Watanabe, J. B. C. da Silva, J. L. V. de Carvalho and M. R. Nutti (2011). Sensory evaluation of cakes prepared with orange-fleshed sweet potato flour (Ipomoeas batatas L.). Perspect Nutr. Humana, 13: 203 211.

Rodrigues, N. da R., J. L. Barbosa Junior and M. I. M. J. Barbosa (2016). Determination of physicochemical composition, nutritional facts and technological quality of organic orange and purple-fleshed sweet potatoes and its flours. Int. Food Res. J., 23(5): 2071-2078.

Salama, A., S. Eldesoaky, M. M. Abul-Fadl, S. H. Bedeir and A. Elmashas (2013). The influence of Xanthan gum or glycerol mono stearate incorporation on the quality characteristics of sponge cake. J. Appl. Sci. Res., 9(1): 53905402.

Shevkani, K. and N. Singh (2014). Influence of kidney bean, field pea and amaranth protein isolates on the characteristics of starch-based glutenfree muffins. Int. J. Food Sci. Technol., 49: 2237-2244.

Shih, L. O., A. A. Adebowale and S. O. Tafa (2006). Proximate, functional, pasting and sensory qualities of instant yam flour. $14^{\text {th }}$ ISTRC 
Symposium, Central Tuber Crops Research Institute, Trivandrum, Kerala State, India.

SPSS (2008). Statistical Package for Social Sciences Program. Version 17 for Windows, SPSS Inc., Chicago.

Srivastava, S., T. R. Genitha and V. Yadav (2012). Preparation and quality evaluation of flour and biscuit from sweet potato. J. Food Process Technol., 3(12): 1-5.

Sumnu, G., S. Sahin and M. Sevimli (2005). Microwave, infrared and infrared-microwave combination baking of cakes. J. Food Eng., 71: 150-155.

Tadesse, T. F., G. Nigusse and H. Kurabachew (2015). Nutritional, Microbial and Sensory Properties of Flat-bread (kitta) Prepared from blends of Maize (Zea mays L.) and orange-fleshed sweet potato (Ipomoea batatas L.) flours. Int. J. Food Sci. and Nutr. Eng., 5(1): 33-39.

Truong, V. D., R. Y. Avula, K. Pecota and C. G. Yencho (2011). Sweet potatoes. In: Handbook of vegetables and vegetable processing. Pp. 717-737. Ames, IA: Blackwell Publishing.

Turabi, E., G. Sumnu and S. Sahin (2008). Rheological properties and quality of rice cakes formulated with different gums and an emulsifier blend. Food Hydrocolloids, (22): 305-312.

Turabi, E., G. Sumnu and S. Sahin (2010). Quantitative analysis of macro and micro-structure of gluten-free rice cakes containing different types of gums baked in different ovens. Food Hydrocolloids, 24: 755-762.

Turker, B., N. Savlak and M. B. Kasikc (2016). Effect of green banana peel flour substitution on physical characteristics of gluten-free cakes. $1^{\text {st }}$ International Multidisciplinary Conference on Nutraceuticals and Functional Foods. Curr. Res. Nutr. Food Sci. J., (SI. 1): 197-204.

Van Hal, M. (2000). Quality of sweet potato flour during processing and storage. Food Rev. Int., 16: 1- 37.

Wen, H., J. Kang, D. Li, W. Wen, F. Yang, H. Hu and C. Chongbo Liu (2016). Antifungal activities of anthocyanins from purple sweet potato in the presence of food preservatives. Food Sci. Biotechnol, 25(1): 165-171

Zuraida, N. (2003). Sweet potato as an alternative food supplement during rice storage. J. Lubang Pertanian, 22(4): 150-155.

\section{تأثير دقيق الذرة البيضاء أو البطاطا الحلوة على خواص الجودة لكيك الأرز الخالية من الجلوتين \\ إيمان عبد الحميل أحمد عبد ربه النيه \\ قسم الاقتصاد المنزلي ـ كلية التربية النو عية - جامعة أسوانـ مصر}

تم تجهيز خلطات كيك خالية من الجلوتين وذللك بإستبدال دقيق الأرز بنسب مختلفة من دقيق الذرة البيضاء أو دقيق البطاطا الحلوة. نم

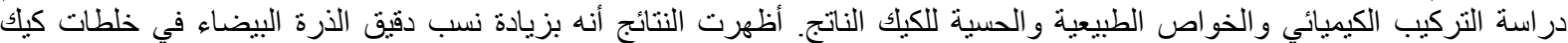

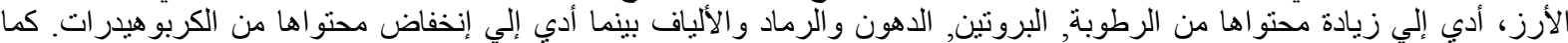

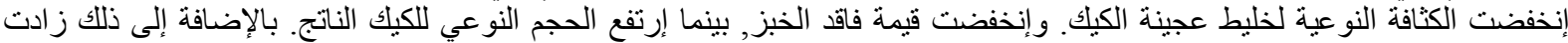

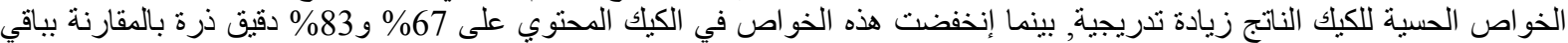

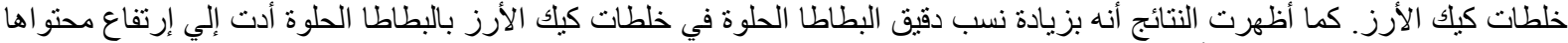

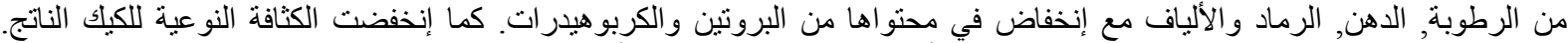

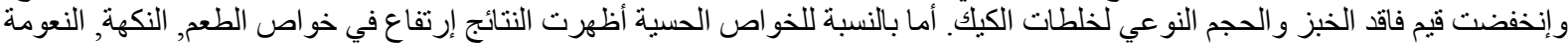

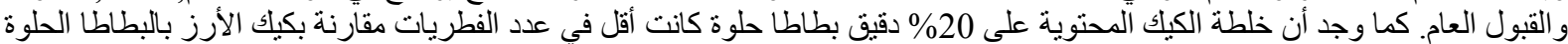

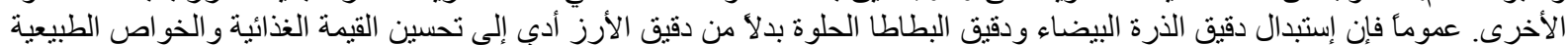

